
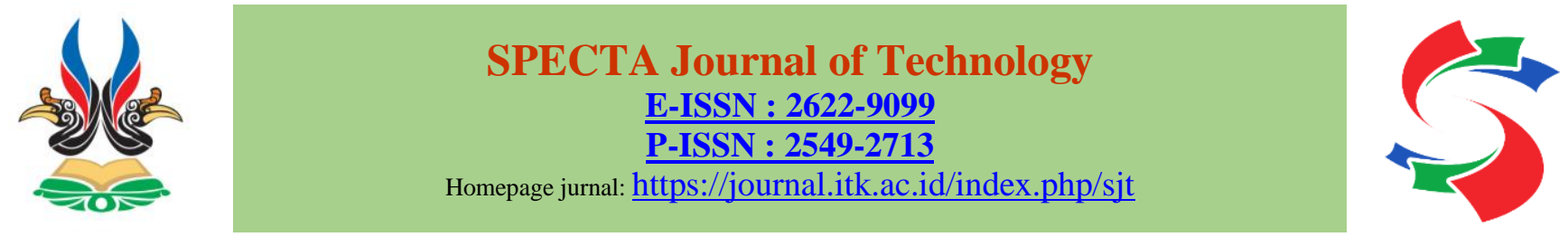

\title{
Kriteria-Kriteria Pemancangan yang Mempengaruhi Pengambilan Keputusan pada Pemilihan Jenis Driven Pile dan Metode Pemancangan
}

\author{
Oryza Lhara Sari ${ }^{1}$, Andina Prima Putri ${ }^{2}$, Christianto Credidi Septino Khala ${ }^{3}$ \\ ${ }^{1,2,3}$ Program Studi Teknik Sipil, Jurusan Teknik Sipil dan Perencanaan, Institut Teknologi Kalimantan, \\ Balikpapan. Email: oryza@lecturer.itk.ac.id
}

\begin{abstract}
In making decisions, practitioners are faced with various conditions that influence the choice of pole type and piling method. The goal of this study to examine the piling criteria that influence the selection of driven pile types and the optimal piling method. Conceptual models are presented as theoretical models from the literature review conducted. The preliminary survey was carried out by identifying the criteria by interviewing four experts who had experience doing foundation building work. The criteria identified by the expert were used for the questionnaire survey. The questionnaire survey was conducted on 45 practitioner respondents who had carried out foundation erection work in Balikpapan. The analysis used to determine the influential criteria is descriptive analysis, nonparametric test (Kruskal-Wallis), validity and reliability tests. The results of the study obtained three main variables which include the piling criteria, the type of driven pile and the piling method. The six determinant staking criteria obtained were soil characteristics, field conditions, building characteristics, cost, time, and previous experience.
\end{abstract}

Keywords: driven pile, piling criteria, piling method, piling, type driven pile.

\begin{abstract}
Abstrak
Pengambilan keputusan membuat praktisi berhadapan dengan berbagai kondisi yang mempengaruhi pemilihan jenis tiang dan metode pemancangan. Penelitian ini bertujuan untuk mengkaji kriteria-kriteria pemancangan yang mempengaruhi pemilihan jenis driven pile dan metode pemancangan yang optimal. Konseptual model disajikan sebagai model teoritis dari literature review yang dilakukan. Survei pendahuluan dilaksanakan dengan mengidentifikasi kriteria dengan wawancara kepada empat expert yang berpengalaman melakukan pekerjaan pemancangan pondasi. Kriteria yang telah diidentifikasi oleh expert digunakan untuk survei kuesioner. Survei kuesioner dilakukan kepada 45 responden praktisi yang pernah melakukan pekerjaan pemancangan pondasi di Balikpapan. Analisis yang digunakan untuk mengetahui kriteria yang berpengaruh adalah analisis deskriptif, uji nonparametrik (Kruskal-Wallis), uji validitas dan reliabilitas. Hasil mendapatkan tiga variabel utama yang meliputi kriteria pemancangan, jenis driven pile dan metode pemancangan. Enam kriteria pemancangan penentu yang didapatkan yaitu karakteristik tanah, kondisi lapangan, karakteristik bangunan, biaya, waktu dan pengalaman sebelumnya.
\end{abstract}

Kata Kunci: driven pile, jenis driven pile, kriteria pemancangan, metode pemancangan, pemancangan.

\section{Pendahuluan}

Struktur bangunan dibagi menjadi dua bagian, yaitu struktur bawah dan struktur atas. Fungsi pondasi adalah sebagai penopang beban dari seluruh struktur yang berada di atas muka tanah. Dari bagian dari struktur, pondasi merupakan bagian yang paling stabil (Ridwan, 2008). 
Beberapa penelitian sebelumnya tentang pemilihan jenis tiang pancang (driven pile) mencoba mengidentifikasi kriteria yang mempengaruhi dalam membuat keputusan yang tepat. Menurut Fauzi dkk. (2016), dalam pemilihan jenis driven pile harus mempertimbangkan kemampuan daya dukung pada tanah dan temuan pada kedalaman tanah keras yang akan mempengaruhi pemilihan bentuk pondasi. Selain itu Fauzi dkk. (2016) mengatakan perlu mempertimbangkan beban dari struktur bangunan bagian atas yang dimana beban tersebut akan ditopang oleh pondasi. Pagehgiri (2015) menyatakan bahwa jenis driven pile yang ada sangat banyak, sehingga pemilihan jenis driven pile harus memperhitungkan beberapa kriteria untuk mendapatkan biaya dan waktu pelaksanaan yang optimal. Sedangkan menurut Tantyonimpuno dan Retnaningtias (2006) kriteria yang diidentifikasi adalah kondisi tanah, teknis pondasi, efisiensi waktu, pelaksanaan, ekonomis, dan lingkungan. Cipta dkk. (2010) juga mengatakan pemilihan jenis pondasi mempertimbangkan kriteria ekonomis, kondisi tanah, efisiensi waktu, pelaksanaan, teknis pondasi, lingkungan, alat dan bahan serta tenaga kerja.

Kriteria selain jenis pondasi, metode pelaksanaan juga perlu dipertimbangkan karena memiliki batasan-batasan terhadap lingkungan (Ridwan, 2008). Menurut Saputra dkk. (2018), pekerjaan pondasi merupakan pekerjaan yang memiliki banyak aspek yang harus dipertimbangkan dan memiliki banyak alternatif jenis driven pile serta metode pemancangan. Sehingga, diperlukan pengetahuan yang unik dengan adanya peraturan yang ketat dan harus diikuti agar kegiatan berjalan ekonomis dan menghindari kerusakan lingkungan dan sosial.

Penyelidikan terhadap kriteria-kriteria yang mempengaruhi pada pemilihan jenis driven pile dan metode pemancangan dapat digunakan praktisi untuk mengatasi permasalahan dari pengalaman sebelumnya. Kriteria-kriteria yang didapatkan juga lebih realistis dan sesuai dengan kondisi yang dialami praktisi serta dapat berpengaruh secara signifikan dalam proses pengambilan keputusan yang akan dilakukan. Selain itu penyelidikan terhadap kriteria-kriteria pada pemilihan jenis driven pile mendapatkan variable baru melalui proses wawancara terhadap ahli yang memberikan manfaat dalam keilmuan kriteria-kriteria pemancangan.

\section{Metode}

\subsection{Variabel Penelitian}

Variabel penelitian yang dibutuhkan adalah kriteria pemancangan dan metode pemancangan. Variabel independen adalah kriteria pemancangan dan variabel intervening adalah jenis driven pile dan metode pemancangan.

Variabel-variabel yang ditentukan kemudian dikelompokkan dalam beberapa golongan untuk memudahkan responden dalam menjawab kuesioner. Responden berjumlah 45 responden yang berasal dari praktisi proyek pemancangan di Balikpapan.

Kriteria-kriteria pemancangan dikelompokkan ke dalam 6 kelompok, yaitu:

1. Karakteristik tanah;

2. Kondisi lapangan;

3. Karakteristik bangunan;

4. Biaya;

5. Waktu; dan

6. Pengalaman sebelumnya.

Pengelompokan kriteria-kriteria yang mempengaruhi pemilihan jenis driven pile dan metode pemancangan pondasi ditunjukkan pada Tabel 1. 
Tabel 1: Pengelompokan kriteria pemancangan

\begin{tabular}{lll}
\hline \multicolumn{1}{c}{ Kriteria } & \multicolumn{1}{c}{ ID } & \multicolumn{1}{c}{$\begin{array}{c}\text { Karakteristik yang Mempengaruhi } \\
\text { Pemilihan Jenis Driven Pile dan Metode } \\
\text { Pemancangan }\end{array}$} \\
\hline Karakteristik tanah & K1 & \multicolumn{1}{c}{$\begin{array}{c}\text { Nilai Standard Penetration Test } \\
\text { K2 }\end{array}$} \\
Kondisi lapangan & K3 & Kedalaman tanah keras \\
& K5 & Lokasi konstruksi \\
Karakteristik bangunan & K6 & Kesehatan dan keselamatan \\
& K7 & Tingkat gangguan yang diizinkan \\
Biaya & K8 & Jenis Bangunan \\
Waktu & K9 & Pertimbangan Biaya \\
Pengalaman sebelumnya & K10 & Batasan Waktu \\
& K11 & Spesifikasi klien \\
& K12 & Kebutuhan ahli geoteknik \\
& K13 & Ketersediaan sumber daya \\
& K14 & Pertimbangan transportasi \\
\hline
\end{tabular}

Sumber: Olahan peneliti, 2020 mengadopsi Sari, 2019; Fauzi dkk., 2016; Prayogo dan Saptowati, 2016; Saputra dkk., 2018; Pagehgiri, 2015; dan Widojoko, 2015.

Keputusan jenis driven pile yang ditentukan oleh praktisi dikelompokkan ke dalam 4 kelompok, yaitu:

1. Kayu;

2. Baja;

3. Beton precast; dan

4. Beton cast in place (bored pile).

Keputusan metode pemancangan pondasi yang ditentukan oleh praktisi dikelompokkan ke dalam dua kelompok, yaitu pemancangan menggunakan penekanan dan pemancangan menggunakan pengeboran.

\subsection{Konseptual Model}

Konsep ini diangkat berawal dari permasalahan yang muncul pada pengambilan keputusan terhadap pemilihan jenis driven pile dan metode pemancangan. Pekerjaan pemancangan pondasi merupakan pekerjaan yang kompleks dan memiliki bermacam kemungkinan terhadap penentuan jenis driven pile dan metode pemancangan. Dengan menganalisis kriteria-kriteria pemilihan jenis driven pile akan diketahui jenis dan metode pemancangannya.

Konseptual model menggunakan model teoritis yang digambarkan dengan menggunakan diagram yang menampilkan hubungan antar konstruk. Konseptual model menghubungkan tiga konstruk, yaitu hubungan antara kriteria pemancangan, jenis driven pile dan metode pemancangan ditunjukkan pada Gambar 1.

\subsection{Wawancara}

Survei pendahuluan bertujuan untuk memverifikasi kriteria yang ditentukan dari beberapa literatur dengan bantuan dari para expert atau praktisi yang berpengalaman pada pekerjaan pemancangan pondasi. Verifikasi ini dilakukan peneliti dengan dibantu oleh empat expert, maka verifikasi oleh para expert ini sudah dianggap valid. 


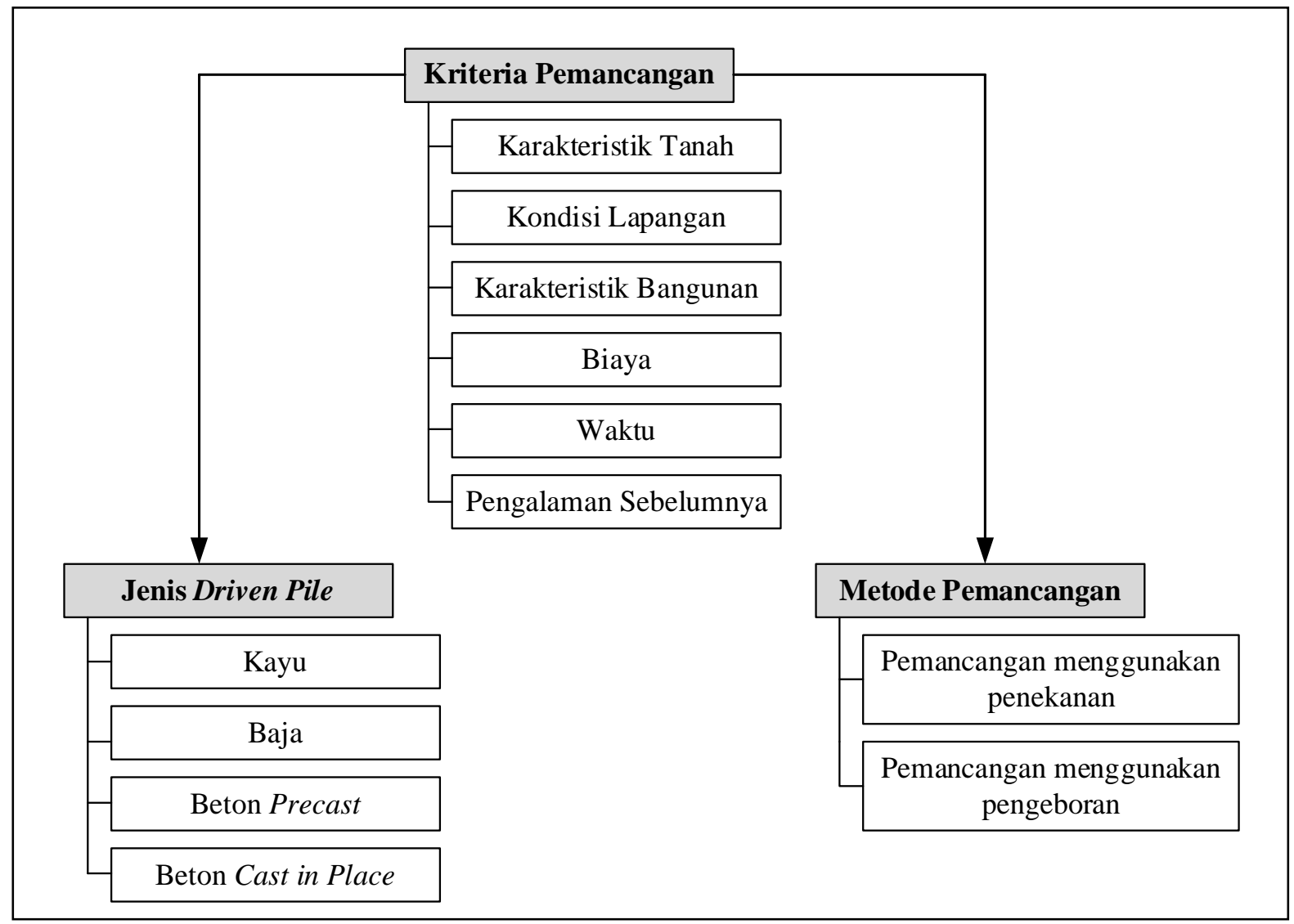

Gambar 1: Konseptual Model

Sumber: Olahan peneliti, 2020 mengadopsi Sari, 2019; Fauzi dkk., 2016; Prayogo dan Saptowati, 2016; Saputra dkk., 2018; Pagehgiri, 2015; dan Widojoko, 2015.

\subsection{Survei Kuesioner}

Pengolahan draft kuesioner dilakukan setelah analisis survei pendahuluan dilaksanakan. Variabelvariabel yang telah lolos uji mean pada analisis survei pendahuluan akan diolah menjadi draft kuesioner dengan tiga bagian, yaitu penilaian variabel, penilaian indikator, dan informasi dan latar belakang responden.

\subsection{Survei Pilot}

Survei pilot dilakukan dengan jumlah sampel $10 \%$ dari total keseluruhan sampel yang direncanakan (Connely, 2008). Pilot survei dilakukan untuk mengetahui apakah draft kuesioner telah layak untuk disebar dan telah dipahami oleh responden. Untuk menilai kuisioner telah layak untuk disebar dan dapat dipahami atau tidak adalah dengan menguji validitas dan reliabilitas terlebih dahulu terhadap sebagian sampel kecil pada pilot survei sebelum dilakukannya penyebaran kuisioner kepada seluruh sampel rencana.

Penyebaran kueisioner dilakukan dengan menggunakan draft kuesioner yang telah diolah sebelumnya. Kuesioner disebarkan kepada 45 sampel dengan kriteria expert/praktisi yang pernah terlibat pada proyek yang melakukan pekerjaan pemancangan pondasi di Balikpapan. Metode pengumpulan data cross section menggunakan dengan berfokus pada analisis kelompok besar persepsi dari responden, dalam hal ini kelompok besar adalah praktisi pemancangan pondasi di Balikpapan.

\subsection{Analisis Protokol}

Analisis pendahuluan diperiksa dan disiapkan guna memastikan bahwa data yang akan digunakan pada analisis telah memenuhi persyaratan. Analisis pendahuluan terdiri dari persiapan data, analisis deskriptif, dan uji nonparametrik. Persiapan data bertujuan untuk memeriksa karakteristik data apakah telah memenuhi asumsi dasar untuk melakukan analisis. Analisis deskriptif bertujuan untuk 
memperoleh karakteristik data serta persepsi para expert dan praktisi tentang kriteria dengan nilai mean, standar deviasi, serta skewness dan kurtosis. Skewness dan kurtosis digunakan untuk mengetahui apakah data terdistribusi normal atau tidak, data dikatakan data distribusi normal jika nilai Z skewness dan Z kurtosis berada di antara -1,96 dan 1,96 (Field, 2009). Uji nonparametrik digunakan untuk menganalisa data yang tidak terdistribusi normal apakah terdapat pengaruh jawaban dalam penilaian pengambilan keputusan yang signifikan dari masing-masing latar belakang responden yang berbeda. Uji nonparametrik yang digunakan adalah uji Kruskal-Wallis dikarenakan data yang diuji memiliki lebih dari dua kelompok dan hanya memiliki satu faktor (Doane dan Seward, 2011); (Priyatno, 2013).

Adapun hipotesis yang diusulkan adalah:

$H_{O}=$ Tidak ada kesenjangan persepsi antar responden berdasarkan posisi jabatan, pengalaman kerja, jumlah proyek dan pendidikan.

$H_{a}=$ Ada kesenjangan persepsi antar responden berdasarkan posisi jabatan, pengalaman kerja, jumlah proyek dan pendidikan.

Menurut Priyatno (2013), untuk menentukan dasar keputusan yang diambil dalam uji Kruskal-Wallis adalah sebagai berikut:

1. Jika nilai $p$-value pada Asymp. Sig > level of significant $(\alpha)$ sebesar 0,05 maka $H_{o}$ harus diterima dan $H_{a}$ harus ditolak.

2. Jika nilai $p$-value pada Asymp. Sig < level of significant $(\alpha)$ sebesar 0,05 maka $H_{o}$ harus ditolak dan $H_{a}$ harus diterima.

Uji validitas digunakan untuk menentukan apakah variabel yang akan digunakan telah valid atau dapat digunakan. Variabel dikatakan valid apabila memenuhi syarat $R_{\text {hitung }}>R_{\text {tabel }}$. Pengujian reliabilitas menggunakan tools alpha cronbach's dimana kuesioner dapat dikatakan reliabel jika cronbach alpha $>0,60$ (Kountur, 2004). Uji validitas dan reliabilitas pada perhitungan dilakukan dengan menggunakan program bantu SPSS.

\section{Hasil dan Pembahasan}

\subsection{Hasil Survei Pendahuluan}

Hasil survei pendahuluan dari para expert (E1, E2, E3 dan E4) memberikan tanggapan mengenai relevansi dari tiap indikator kriteria. Untuk pengukuran relevansi, tanggapan dari para expert disajikan menggunakan uji mean yang ditunjukkan pada Tabel 2. Tiap indikator pada masing-masing tabel diurutkan berdasarkan nilai mean, semakin tinggi nilai mean maka semakin relevan kriteria tersebut sebagai penentu dalam pengambilan keputusan jenis driven pile dan metode pemancangan (Sugiyono, 2010). 
Tabel 2: Respon expert pada kriteria pemancangan

\begin{tabular}{llllllll}
\hline \multicolumn{1}{c}{ ID } & \multicolumn{1}{c}{ Kriteria Pemancangan } & E1 & E2 & E3 & E4 & Mean & Kesimpulan \\
\hline K1 & Nilai Standard Penetration Test & 5 & 4 & 5 & 5 & 4,75 & Relevan \\
K3 & Kedalaman tanah keras & 5 & 5 & 5 & 4 & 4,75 & Relevan \\
K2 & Jenis tanah & 5 & 4 & 5 & 4 & 4,5 & Relevan \\
K13 & Ketersediaan sumber daya & 5 & 4 & 5 & 4 & 4,5 & Relevan \\
K7 & Skala konstruksi & 4 & 3 & 5 & 4 & 4 & Relevan \\
K8 & Jenis bangunan & 4 & 3 & 5 & 4 & 4 & Relevan \\
K11 & Spesifikasi klien & 5 & 4 & 5 & 2 & 4 & Relevan \\
K6 & Tingkat gangguan & 3 & 4 & 5 & 3 & 3,75 & Cukup relevan \\
K9 & Pertimbangan biaya & 3 & 3 & 5 & 4 & 3,75 & Cukup relevan \\
K12 & Kebutuhan ahli geoteknik & 5 & 3 & 3 & 4 & 3,75 & Cukup relevan \\
K14 & Pertimbangan transportasi & 5 & 3 & 5 & 2 & 3,75 & Cukup relevan \\
K4 & Lokasi konstruksi & 4 & 2 & 5 & 3 & 3,5 & Cukup relevan \\
K5 & Kesehatan dan keselamatan & 3 & 1 & 5 & 3 & 3 & Cukup relevan \\
K10 & Batasan waktu & 2 & 3 & 5 & 2 & 3 & Cukup relevan \\
\hline
\end{tabular}

Sumber: Olahan peneliti, 2020.

Jumlah skor pada kriteria pemancangan jika setiap indikator mendapat skor tertinggi $=5 \times 14 \times 4=$ 280. Skor tertinggi tiap butir $=5$, total indikator $=14$, dan jumlah responden expert $=4$. Jumlah skor hasil dari respon para expert adalah $=220$. Maka, indikator pada kriteria pemancangan menurut respon dari 4 expert adalah $220 / 280=0,78$ atau $78 \%$. Nilai $78 \%$ termasuk dalam kategori interval "relevan", dan nilai skor tiga $(3,00)$ digunakan sebagai cut-off (Sugiyono, 2010). Mean dari tiap indikator harus lebih tinggi dari 3,00 agar indikator dianggap relevan untuk menjadi penentu dalam pengambilan keputusan. Dalam kriteria pemancangan, semua indikator mendapatkan nilai di atas cut-off. Maka dengan itu semua 14 indikator pada kriteria pemancangan dianggap relevan sebagai indikator penentu pengambilan keputusan yang akan digunakan pada survei kuesioner.

Jumlah indikator pada kriteria pemancangan sebelum dilakukan reduksi berdasarkan respon para expert adalah 14. Setelah dilakukan uji mean 14 indikator dari kriteria pemancangan digunakan untuk survei selanjutnya. Untuk kriteria pemancangan yang akan digunakan sebagai penentu antara lain nilai Standard Penetration Test (SPT), kedalaman tanah keras, jenis tanah, lokasi konstruksi, kesehatan dan keselamatan, tingkat gangguan yang diizinkan, skala konstruksi, jenis bangunan, pertimbangan biaya, batasan waktu, spesifikasi klien, kebutuhan ahli geoteknik, ketersediaan sumber daya, dan pertimbangan transportasi.

\subsection{Hasil Data Pilot Survei}

Pilot survei digunakan untuk menilai apakah kuesioner telah layak untuk disebar dan menjadi tolak ukur pemahaman responden terhadap tiap indikator pada isi kuesioner. Kuesioner yang diserahkan kepada pilot merupakan kuesioner yang indikator-indikatornya telah direduksi dari survei pendahuluan. Connelly (2008) mengatakan bahwa jumlah sampel pada survei pilot harus berjumlah $10 \%$ dari jumlah sampel yang akan direncanakan pada akhir. Maka, jumlah responden yang diambil untuk survei pilot sebanyak 10\% dari 45 responden, yaitu 5 sampel (R1, R2, R3, R4 dan R5) yang dipilih secara acak dari total keseluruhan responden. Berikut adalah respon dari pilot terhadap kriteria pemancangan yang ditunjukkan pada Tabel 3 . 
Tabel 1: Respon pilot pada kriteria pemancangan

\begin{tabular}{lllllllll}
\hline ID & \multicolumn{1}{c}{ Kriteria Pemancangan } & R1 & R2 & R3 & R4 & R5 & Mean & Kesimpulan \\
\hline K1 & Nilai Standard Penetration Test & 5 & 5 & 4 & 5 & 5 & 4,8 & Relevan \\
K8 & Jenis bangunan & 4 & 5 & 5 & 5 & 5 & 4,8 & Relevan \\
K2 & Jenis tanah & 5 & 4 & 5 & 4 & 5 & 4,6 & Relevan \\
K3 & Kedalaman tanah keras & 4 & 5 & 4 & 5 & 5 & 4,6 & Relevan \\
K6 & Tingkat gangguan & 4 & 4 & 5 & 4 & 5 & 4,4 & Relevan \\
K11 & Spesifikasi klien & 5 & 4 & 5 & 4 & 4 & 4,4 & Relevan \\
K14 & Pertimbangan transportasi & 5 & 4 & 3 & 5 & 5 & 4,4 & Relevan \\
K4 & Lokasi konstruksi & 4 & 5 & 4 & 3 & 5 & 4,2 & Relevan \\
K9 & Pertimbangan biaya & 5 & 4 & 4 & 4 & 4 & 4,2 & Relevan \\
K10 & Batasan waktu & 5 & 4 & 4 & 4 & 4 & 4,2 & Relevan \\
K12 & Kebutuhan ahli geoteknik & 4 & 4 & 4 & 4 & 4 & 4 & Relevan \\
K13 & Ketersediaan sumber daya & 3 & 4 & 4 & 4 & 5 & 4 & Relevan \\
K5 & Kesehatan dan keselamatan & 3 & 3 & 4 & 4 & 5 & 3,8 & Cukup relevan \\
K7 & Skala konstruksi & 2 & 4 & 4 & 4 & 5 & 3,8 & Cukup relevan \\
\hline S
\end{tabular}

Sumber: Olahan Peneliti, 2020.

Jumlah skor pada kriteria pemancangan jika setiap indikator mendapat skor tertinggi $=5 \times 14 \times 5=$ 350. Skor tertinggi tiap butir $=5$, total indikator $=14$, dan jumlah pilot $=5$. Jumlah skor hasil dari respon para pilot adalah $=301$. Indikator pada kriteria pemancangan menurut para pilot adalah $301 / 350=0,86$ atau $86 \%$ yang dimana termasuk dalam kategori interval "sangat relevan" (Sugiyono, 2010). Nilai mean yang diperoleh dari tiap indikator tidak ada yang memiliki nilai dibawah dari nilai cut-off 3.00, sebagian besar indikator memperoleh nilai di atas 4,00.

Berdasarkan analisa tersebut, terdapat perubahan nilai relevansi yang cukup signifikan setelah direduksinya kuesioner pada survei pendahuluan. Variabel kriteria pemancangan memiliki nilai relevansi, yaitu $86 \%$ atau "sangat relevan", yang berarti dapat ditarik kesimpulan para responden pilot memberi nilai yang tinggi pada tiap indikator dan telah memahami isi dan maksud dari kuesioner. Nilai mean yang diperoleh dari tiap indikator kriteria memiliki nilai di atas 4,00 atau "relevan", yang berarti indikator yang tertera telah relevan untuk digunakan dalam penentuan pengambilan keputusan jenis driven pile dan metode pemancangan dan dapat dilanjutkan ke tahap survei kuesioer.

\subsection{Analisis Deskriptif}

Pada analisis ini didapatkan nilai mean, standar deviasi, serta skewness dan kurtosis untuk menentukan apakah data terdistribusi normal atau tidak (Field, 2009). Jika data tidak terdistribusi normal, maka perlu dilakukannya uji nonparametrik untuk menganalisa jawaban antar kelompok.

Data dapat dikatakan terdistribusi normal jika nilai Z skewness dan Z kurtosis berada di antara $-1,96$ dan 1,96 (Field, 2009). Berdasarkan nilai $\mathrm{Z}$ atau kemiringan dari skewness dan kurtosis yang dihasilkan, didapatkan bahwa data kuesioner yang diperoleh sebagian besar tidak terdistribusi normal, hanya dua indikator yang terdistribusi normal, yaitu K5 (kesehatan dan keselamatan), K12 (kebutuhan ahli geoteknik). Maka diperlukan uji nonparametrik (Kruskal-Wallis) untuk menganalisa lebih dalam apakah keragaman jawaban memiliki kesinambungan terhadapat latar belakang responden.

\subsection{Uji Nonparametrik (Uji Kruskal-Wallis)}

Berdasarkan 45 data kuesioner yang diperoleh, diketahui bahwa sebagian besar data tidak tergolong data distribusi normal, maka perlu dilakukannya analisis nonparametrik berdasarkan latar belakang responden. Dalam hal ini adalah posisi jabatan, pengalaman kerja, jumlah proyek dan pendidikan terakhir. 


\subsubsection{Pengaruh posisi jabatan responden terhadap penilaian pengambilan keputusan}

Posisi jabatan responden dikelompokkan menjadi enam kelompok berdasarkan data kuesioner, yaitu antara lain direktur, engineering, site engineering, komersial, QA/QC, dan estimator. Berdasarkan hasil uji Kruskal-Wallis, semua variabel memperoleh nilai Asymp. Sig. lebih besar dari 0,05 yang berarti $H_{o}$ harus diterima dan $H_{a}$ harus ditolak untuk semua variabel, kecuali untuk variabel K2 di mana ada perbedaan persepsi responden berdasarkan posisi jabatan. Maka, pada semua indikator kecuali K2 (jenis tanah), semua responden dengan posisi jabatan yang beragam tidak memiliki perbedaan persepsi dalam menanggapi kriteria yang mungkin terjadi pada pengambilan keputusan pemilihan jenis driven pile dan metode pemancangan.

\subsubsection{Pengaruh posisi jabatan responden terhadap penilaian pengambilan keputusan}

Pengalaman kerja responden dikelompokkan menjadi empat kelompok, yaitu antara lain responden dengan pengalaman kerja kurang dari 5 tahun, antara 5 sampai 10 tahun, antara 10 sampai 20 tahun, dan yang memiliki pengalaman lebih dari 20 tahun. Berdasarkan hasil uji Kruskal-Wallis di atas, semua variabel memperoleh nilai Asymp. Sig. lebih besar dari 0,05 yang berarti $H_{o}$ harus diterima dan $H_{a}$ harus ditolak untuk semua variabel, kecuali untuk variabel K8 dan K9 di mana ada perbedaan persepsi responden berdasarkan pengalaman kerja mereka. Maka, pada semua indikator kecuali K8 (jenis bangunan) dan K9 (pertimbangan biaya) semua responden dengan pengalaman kerja yang beragam tidak memiliki perbedaan persepsi dalam menanggapi kriteria yang mungkin terjadi pada pengambilan keputusan pemilihan jenis driven pile dan metode pemancangan.

\subsubsection{Pengaruh jumlah proyek responden terhadap penilaian pengambilan keputusan}

Jumlah proyek pemancangan yang dilakukan oleh responden dikelompokkan menjadi enam kelompok, yaitu antara lain responden dengan jumlah 1-2 proyek 3-4 proyek, 5-6 proyek, 7-8 proyek, 9-10 proyek, dan lebih dari 10 proyek. Berdasarkan hasil uji Kruskal-Wallis di atas, semua variabel memperoleh nilai Asymp. Sig. lebih besar dari 0,05 yang berarti $H_{o}$ harus diterima dan $H_{a}$ harus ditolak untuk semua variabel. Maka, pada semua indikator seluruh responden dengan jumlah proyek pemancangan yang beragam tidak memiliki perbedaan persepsi dalam menanggapi kriteria yang mungkin terjadi pada pengambilan keputusan pemilihan jenis driven pile dan metode pemancangan.

\subsubsection{Pengaruh pendidikan responden terhadap penilaian pengambilan keputusan}

Pendidikan terakhir dari responden dikelompokkan menjadi empat kelompok, yaitu responden dengan pendidikan terakhir SMA/SMK, D3, S1, dan S2. Berdasarkan hasil uji Kruskal-Wallis di atas, semua variabel memperoleh nilai Asymp. Sig. lebih besar dari 0,05 yang berarti $H_{o}$ harus diterima dan $H_{a}$ harus ditolak untuk semua variabel. Maka, pada semua indikator seluruh responden dengan pendidikan terakhir yang beragam tidak memiliki perbedaan persepsi dalam menanggapi kriteria yang mungkin terjadi pada pengambilan keputusan pemilihan jenis driven pile dan metode pemancangan.

\subsection{Hasil Uji Validitas dan Reliabilitas Survei Kuesioner}

Uji validitas dan reliabilitas menggunakan program bantu IBM SPSS versi 26. Berikut adalah hasil uji validitas untuk kriteria yang ditunjukkan pada Tabel 4. Digunakan $R_{\text {tabel }}$ dengan nilai 0,248 (N=45). 
Tabel 4: Hasil uji validitas kriteria pemancangan

\begin{tabular}{llllc}
\hline \multicolumn{1}{c}{ ID } & \multicolumn{1}{c}{ Kriteria Pemancangan } & & Kesimpulan \\
\hline K1 & Nilai SPT & 0.370 & 0.248 & Valid \\
K2 & Jenis tanah & 0.268 & 0.248 & Valid \\
K3 & Kedalaman tanah keras & 0.568 & 0.248 & Valid \\
K4 & Lokasi konstruksi & 0.633 & 0.248 & Valid \\
K5 & Kesehatan dan keselamatan & 0.493 & 0.248 & Valid \\
K6 & Tingkat gangguan yang diizinkan & 0.404 & 0.248 & Valid \\
K7 & Skala konstruksi & 0.607 & 0.248 & Valid \\
K8 & Jenis bangunan & 0.335 & 0.248 & Valid \\
K9 & Pertimbangan Biaya & 0.339 & 0.248 & Valid \\
K10 & Batasan Waktu & 0.267 & 0.248 & Valid \\
K11 & Spesifikasi klien & 0.502 & 0.248 & Valid \\
K12 & Kebutuhan ahli geoteknik & 0.565 & 0.248 & Valid \\
K13 & Ketersediaan sumber daya & 0.742 & 0.248 & Valid \\
K14 & Pertimbangan transportasi & 0.625 & 0.248 & Valid \\
\hline
\end{tabular}

Sumber: Olahan peneliti, 2020.

Dikarenakan semua nilai $R_{\text {hitung }}$ yang dihasilkan lebih besar dari $R_{\text {tabel }}$, maka didapatkan kesimpulan bahwa 14 indikator pada kriteria pemancangan yang digunakan adalah valid.

Pada uji reliabilitas, digunakan cut-off dengan nilai 0,6 sebagai syarat agar variabel dapat dikatakan reliabel (Kountur, 2004). Berikut adalah hasil uji reliablitas untuk kriteria yang ditunjukkan pada Tabel 5 sebagai berikut.

Tabel 5: Hasil uji reliabilitas kriteria pemancangan

\begin{tabular}{cccc}
\hline \multicolumn{1}{c}{ Variabel } & Cronbach Alpha & Cut-Off & Kesimpulan \\
\hline Kriteria Pemancangan & 0,741 & 0,6 & Reliabel \\
\hline
\end{tabular}

Sumber: Olahan peneliti, 2020.

Berdasarkan hasil uji reliabilitas, maka dapat disimpulkan bahwa sampel yang digunakan memiliki konsistensi jawaban atau reliabel yang baik.

\subsection{Diagram Model Variabel}

Data yang diperoleh dari 45 responden setelah uji validitas dan uji reliabilitas digunakan sebagai dasar dari diagram model variabel dalam memprediksi pengambilan keputusan jenis driven pile dan pemancangan ditunjukkan pada Gambar 2. Data yang digunakan memiliki 3 variabel utama, yaitu kriteria pemancangan (independen), jenis driven pile (intervening), dan metode pemancangan (intervening). 


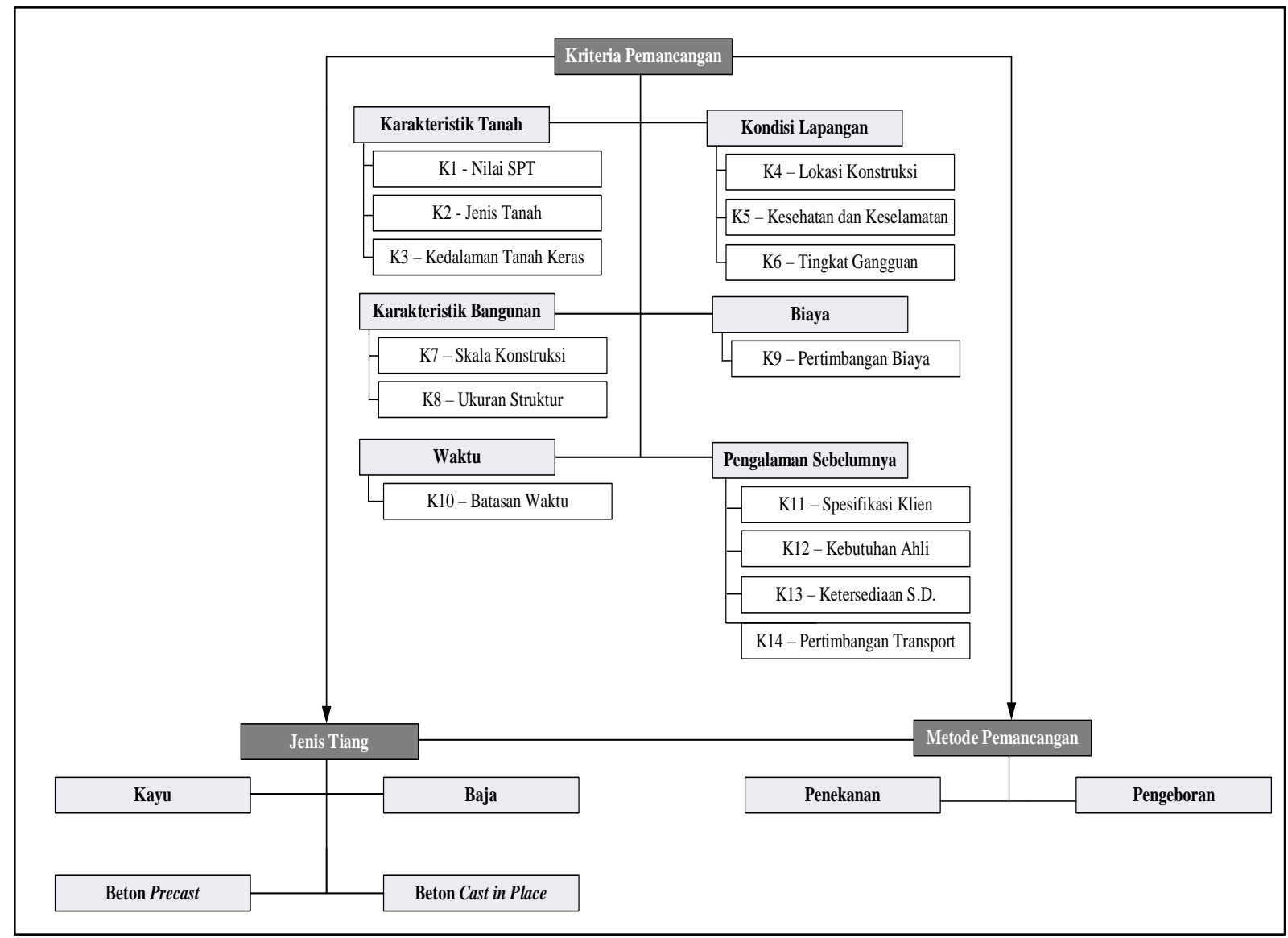

Gambar 2: Diagram Model Variabel Sumber: Olahan peneliti, 2020.

Dari Gambar 2, dapat dilihat pada kriteria pemancangan memiki 6 kriteria utama yang menjadi pertimbangan dalam menentukan jenis driven pile dan metode pemancangan, yaitu karakteristik tanah, kondisi lapangan, karakteristik bangunan, biaya, waktu, dan pengalaman sebelumnya. Dari 6 kriteria utama tersebut dipecah lagi menjadi 14 kriteria pemancangan dalam pemilihan jenis driven pile dan metode pemancangan. 14 kriteria tersebut, antara lain nilai SPT, jenis tanah, kedalaman tanah keras, lokasi konstruksi, kesehatan dan keselamatan, tingkat gangguan, skala konstruksi, jenis bangunan, pertimbangan biaya, batasan waktu, spesifikasi klien, kebutuhan ahli geoteknik, ketersediaan sumber daya, dan pertimbangan transportasi.

\section{Kesimpulan}

Kriteria utama yang mempengaruhi praktisi dalam mengambil keputusan pemilihan jenis driven pile dan metode pemancangan, yaitu karakteristik tanah, kondisi lapangan, karakteristik bangunan, biaya, waktu, dan pengalaman sebelumnya. Kriteria utama tersebut dibagi menjadi empat belas kriteria yang diurutkan berdasarkan bobot masing-masing indikator. Empat belas kriteria tersebut, antara lain nilai SPT, jenis tanah, kedalaman tanah keras, ukuran struktur, lokasi konstruksi, pertimbangan transportasi, tingkat gangguan yang diizinkan, batasan waktu, spesifikasi klien, ketersediaan sumber daya, pertimbangan biaya, kesehatan dan keselamatan, kebutuhan ahli geoteknik, dan skala konstruksi.

\section{Ucapan Terima Kasih}

Para penulis berterima kasih atas perhatian dan bantuan dari Institut Teknologi Kalimantan dalam bentuk kegiatan "Hibah Penelitian dan Pengabdian Masyarakat Institut Teknologi Kalimantan Tahun 2020, Nomor kontrak: 1134 / IT10 / PPM.05 / 2020". Semua konsep dan hasil yang disajikan dalam makalah ini adalah bagian dari penelitian berjudul "Model Pengambilan Keputusan Pada Pemilihan Jenis Driven Pile dan Metode Pemancangan Pondasi Berbasis Multiclass Multilabel Classification". 


\section{Daftar Pustaka}

Cipta, M., Wijaya, G. P., Hermawan, dan Wibowo, M. A. (2010) 'Analisa studi penggunaan AHP pada pengambilan keputusan pemilihan jenis sub struktur pada proyek konstruksi' dalam Konferensi Nasional Teknik Sipil 4, Bali, Indonesia: KoNTekS 4.

Connelly, L. M. (2008) 'Pilot studies', Medsurg Nursing, Vol. 17, No. 6: 411.

Doane, D. dan Seward, L. E. (2011) Applied Statistics in Business and Economics, New York: McGraw-Hill Education.

Fauzi, L. A. dan Ikhya (2016) 'Analisis kapasitas daya dukung pondasi dangkal tipe menerus pengaruh kedalaman tanah keras', RekaRacana: Jurnal Teknik Sipil, Vol. 2, No. 2: 36-46.

Field, A. (2009) Discovering Statistics Using SPSS 3rd Edition, London: Sage Publications Ltd.

Kountur, R. (2004) Metode Penelitian untuk Penulisan Skripsi dan Tesis, Jakarta: PPM.

Pagehgiri, J. (2015) 'Analisis penggunaan pondasi mini pile dan pondasi borpile terhadap biaya dan waktu pelaksanaan pembangunan ruang kelas SMPN 10 Denpasar', Jurnal Teknik Sipil Untag Surabaya, Vol. 8, No. 1: 121-136.

Prayogo, K. dan Saptowati, H. (2016) 'Penyelidikan struktur dan karakteristik tanah untuk desain pondasi iradiator gamma kapasitas 2 MCi', Jurnal Perangkat Nuklir PRFN-BATAN, Vol. 10, No. 1: 30-49.

Priyatno, D. (2013) Mandiri Belajar Analisis Data Dengan SPSS, Yogyakarta: MediaKom.

Ridwan, M. (2008) 'Pengaruh getaran pemasangan pondasi tiang pancang terhadap lingkungan permukiman', Jurnal Permukiman, Vol. 3, No. 1: 44-54.

Saputra, T. H., Habir, dan Munajir, A. (2018) 'Perbandingan desain alternatif pondasi dalam pada proyek pembangunan jembatan fly over simpang air hitam Kota Samarinda', Jurnal Universitas 17 Agustus 1945 Samarinda, Vol. 1, No. 1: 1-15.

Sari, O. L., Adi, T. J. W., dan Munif, A. (2019) 'Selection model of building demolition method based on expert system’ dalam Proceedings of the Third International Conference on Sustainable Innovation 2019, Yogyakarta, Indonesia: ICoSI.

Sugiyono (2010) Metode Penelitian Kuantitatif, Kualitatif, dan R\&D, Bandung: Alfabeta.

Tantyonimpuno, R. S. dan Retnaningtias, A. D. (2006) 'Penerapan metode Analytical Hierarchy Process (AHP) pada proses pengambilan keputusan pemilihan jenis pondasi', Jurnal Teknik Sipil Unika Soegijapranata, Vol. 3, No. 2, hal. 77-87.

Widojoko, L. (2015) 'Analisa dan desain pondasi tiang pancang berdasarkan bentuk tiang', Jurnal Teknik Sipil $U B L$, Vol. 6, No. 2: 818-842. 